\title{
Grzegorz Koziel*
}

\section{UZGODNIENIE PRZEZNACZENIA JAKO PRZESLANKA KORZYSTANIA Z UTWORU NAUKOWEGO PRZEZ INSTYTUCJE NAUKOWĄ POPRZEZ JEGO UDOSTĘPNIANIE OSOBOM TRZECIM W ZAKRESIE OKREŚLONYM W ART. 14 UST. 2 IN FINE USTAWY O PRAWIE AUTORSKIM I PRAWACH POKREWNYCH ${ }^{1}$}

\section{Streszczenie}

W artykule przedstawiono uwagi na temat uzgodnionego przeznaczenia stanowiącego zgodnie z art. 14 ust. 2 u.p.a.p.p. podstawę udostępniania przez instytucję naukową utworu naukowego stworzonego przez jej pracownika osobom trzecim. Określono w nim w szczególności relację prawną między uzgodnieniem przeznaczenia a umową, z której takie uzgodnienie może wynikać, zaproponowano kwalifikację prawną uzgodnienia przeznaczenia i wynikającego z niego uprawnienia instytucji naukowej z perspektywy przymiotów tego uzgodnienia kluczowych z punktu widzenia jego charakteru prawnego, a także wskazano na zasadnicze relacje między dopuszczalnymi prawnie obszarami udostępniania utworu naukowego a właściwościami tego utworu. W artykule odniesiono się również do kwestii zasadności uzależniania nieodpłatności i zakresu udostępniania utworu naukowego od celu tego udostępnienia, a ponadto do zagadnienia terminowości oraz zmiany uzgodnienia przeznaczenia. Finalną część artykułu stanowią wnioski podsumowujące najważniejsze spostrzeżenia przywołane w jego treści.

Słowa kluczowe: instytucja naukowa, uzgodnienie przeznaczenia, utwór naukowy, udostępnianie utworu naukowego osobom trzecim, obszary udostępnienia dowskiej

dr hab. Grzegorz Kozieł, Wydział Prawa i Administracji Uniwersytetu Marii Curie-Skło-

1 Ustawa z dnia 4 lutego1994 r. o prawie autorskim i prawach pokrewnych, tekst jedn. Dz. U. z 2017 r., poz. 880, ze zm. - dalej u.p.a.p.p. 


\section{Zakres unormowania art. 14 ust. 2 u.p.a.p.p. a prawo instytucji naukowej do udostępniania utworu naukowego osobom trzecim}

Zgodnie z art. 14 ust. 2 u.p.a.p.p. instytucji naukowej przysługuje, poza uprawnieniem do korzystania $\mathrm{z}$ materiału naukowego zawartego $\mathrm{w}$ utworze naukowym $^{2}$ (w zasadzie korzystania z utworu o charakterze naukowym ${ }^{3}$ ), prawo do udostępniania tego utworu osobom trzecim - jeżeli wynika to z uzgodnionego przeznaczenia utworu lub zostało postanowione w umowie. Dostrzegam występujące $\mathrm{w}$ literaturze przedmiotu określone wątpliwości związane $\mathrm{z}$ interpretacją art. 14 ust. 2 u.p.a.p.p. ${ }^{4}$ i zaznaczam, że pozostawiając to zagadnienie otwarte do ewentualnej dyskusji, przyjmuję, iż zawarte w tym przepisie sformułowanie: ,jeżeli wynika to z uzgodnionego przeznaczenia utworu lub zostało postanowione w umowie" odnosi się wprost jedynie do prawa instytucji naukowej do udostępniania utworu naukowego osobom trzecim. W niniejszej wypowiedzi chciałbym podzielić się kilkoma uwagami dotyczącymi uzgodnienia przeznaczenia jako przesłanki właśnie tego drugiego z wymienionych w art. 14 ust. 2 u.p.a.p.p. uprawnień instytucji naukowej.

Podmiotem uprawnionym na podstawie wyżej wymienionego przepisu jest instytucja naukowa ${ }^{5}$. Instytucji tej przysługuje względne (skuteczne w stosunku

2 W kwestii pojęcia utworu naukowego zob. zwł. J. Błeszyński, Ochrona utworów naukowych, technicznych i popularno-naukowych w świetle polskiego prawa autorskiego, „Wiadomości ZAiKS-u” 1981, nr 1-2, s. 21; A. Szewc, Dzieła naukowe i ich status w polskim prawie autorskim, „Państwo i Prawo" 1997, z. 10, s. 24 i n.; E. Ferenc-Szydełko, Ochrona dziet naukowych w świetle prawa autorskiego, „Zeszyty Naukowe Uniwersytetu Szczecińskiego” 2004, z. 14, s. 155 i n.; P. Stec, Uczelnia jako podmiot praw na dobrach niematerialnych, „Państwo i Prawo” 2008, z. 1, s. 51; A. Niewęgłowski, Wyniki prac badawczych w obrocie cywilnoprawnym, Warszawa 2010, s. 170-177 i przywołana tam literatura.

3 Zob. M. Poźniak-Niedzielska, G. Tylec, Działalność naukowo-dydaktyczna na wyższej uczelni w świetle prawa autorskiego, „Państwo i Prawo” 2009, z. 5, s. 33-48.

4 Zdaniem A. Nowickiej (System prawa prywatnego, t. 13: Prawo autorskie, red. J. Barta, Warszawa 2007, s. 101), J. Barty (Komentarz do art. 14 ust. 2 u.p.a.p.p., LEX/el. 2011, pkt 7 i n.) i D. Flisaka (Komentarz do art. 14 u.p.a.p.p., LEX/el. 2015) jakkolwiek brzmienie art. 14 ust. 2 u.p.a.p.p. może być dyskusyjne, określenie ,jeżeli wynika to z uzgodnionego przeznaczenia utworu lub zostało postanowione w umowie" odnosi się do każdego z wymienionych w tym przepisie uprawnień instytucji naukowej; odmienny, jak można sądzić, pogląd w tej sprawie wyraziła M. Poźniak-Niedzielska i G. Tylec (Działalnośćc..., s. 33-48), których zdaniem sformułowanie to dotyczy prawa instytucji naukowej do udostępniania utworu naukowego osobom trzecim. Chociaż, jak już wspomniano, może to budzić określone wątpliwości, opowiadam się za drugim z przywołanych poglądów.

$5 \mathrm{Na}$ temat kategorii instytucji naukowych i jednostek naukowych zob. zwł. A. Kędzierska-Cieślak, Pierwszeństwo instytucji naukowej do opublikowania utworu naukowego jej pracownika, „Państwo i Prawo” 1996, z. 8-9, s. 81 i n.; P. Stec, Uczelnia..., s. 51; A. Niewęgłowski, Wyniki..., s. $66-74,189-192$. 
do podmiotu praw autorskich - twórcy utworu naukowego ${ }^{6}$ ) uprawnienie do udostępniania utworu naukowego osobom trzecim. Swego rodzaju „beneficjentem” tego uprawnienia są osoby trzecie, a zatem inne niż twórca utworu naukowego, instytucja i jej pracownicy. W każdym przypadku podstawą udostępniania jest określonego rodzaju relacja prawna o charakterze umownym powstała między instytucją naukową i jej pracownikiem. Jest nią najczęściej umowa zawarta między instytucją naukową a jej pracownikiem (w tym zwykle umowa o pracę), w której jej strony, zgodnie z art. 14 ust. 2 u.p.a.p.p. uzgodniły przeznaczenie utworu naukowego (utworów naukowych), obejmujące jego (ich) udostępnienie osobom trzecim na warunkach określonych w tej umowie albo też zawarte poza tą umową, istniejące obok niej, porozumienie zawierające uzgodnienie przeznaczenia wymienionego utworu (utworów), które można traktować jako rodzaj czynności prawnej nienazwanej - ,pozaumowne porozumienie w kwestii uzgodnienia przeznaczenia”. Zarówno dla oznaczenia postanowień umowy między instytucją naukową a jej pracownikiem w obszarze uzgodnionego przeznaczenia utworu naukowego (utworów naukowych), jak i wymienionego wyżej, istniejącego poza tą umową porozumienia o tej treści w niniejszej wypowiedzi używam określenia „uzgodnienie przeznaczenia”.

\section{Umowa między instytucją naukową i jej pracownikiem a zawarte i istniejące poza tą umową „uzgodnienie przeznaczenia” utworu naukowego jako podstawy prawne uprawnienia osób trzecich przewidzianego w art. 14 ust. 2 u.p.a.p.p.}

Dokonane na podstawie art. 14 ust. 2 u.p.a.p.p. uzgodnienie przeznaczenia utworu naukowego może być zawarte w umowie (jak można sądzić, co wynika z wykładni systemowej, a ściślej mieszczącego się w jej ramach kontekstu regulacyjnego wyżej wymienionego przepisu względem art. 14 ust. 1 u.p.a.p.p., przede wszystkim w umowie o pracę, zwartej między instytucją naukową a twórcą pracownikiem naukowym) albo pozaumownym porozumieniu o tej treści. Pozaumowne porozumienie (uzgodnienie przeznaczenia) może być sporządzone w formie pisemnej (jak trzeba uznać, jedynie dla celów dowodowych) albo może mieć postać choćby ustnego uzgodnienia, którego istotnym elementem będzie

6 J. Barta, Komentarz do art. 14 ust. 1 u.p.a.p.p., LEX/el. 2011 - w odróżnieniu od uprawnienia przewidzianego $\mathrm{w}$ art. 14 ust. 1 u.p.a.p.p., któremu przypisuje się charakter prawa bezwzględnego - tak np. M. Poźniak-Niedzielska, G. Tylec, Działalność..., s. 33-48. 
przynajmniej świadomość twórcy dotycząca zakresu akceptowanego udostępniania utworu naukowego ${ }^{7}$. Wydaje się, że może być to uzgodnienie konkretne (przedmiotowo i zakresowo ściśle określone), dotyczące utworów, do których stworzenia zobowiązał się pracownik naukowy, albo uzgodnienie bardziej generalne (ogólne), odnoszące się do określonej kategorii (rodzaju) utworów naukowych ${ }^{8}$.

$\mathrm{Z}$ tej perspektywy sformułowanie przepisu art. 14 ust. 2 u.p.a.p.p., stwierdzające, że podstawą udostępnienia utworu naukowego może być umowa, należałoby uznać za zbędne, skoro uzgodnienie przeznaczenia, jak wypada sądzić, może mieć postać pozaumowną ( $\mathrm{w}$ tym, w szczególności być zawarte poza umową o pracę) lub umowną (wynikać z tej umowy) ${ }^{9}$. Oczywiście regulację tę można ewentualnie interpretować jako podstawę określonej normy o charakterze instrukcyjnym (albo podstawę określonego rodzaju reguły o znaczeniu interpretacyjnym), zgodnie z którą w przypadku, gdy nie ma umowy (która jest podstawą uzgodnienia przeznaczenia utworu naukowego), natomiast z uzgodnionego przeznaczenia utworu wynika podstawa do udostępnienia tego utworu osobom trzecim, istnieje możliwość takiego udostępnienia. W każdym wypadku chodzi o przeznaczenie utworu naukowego, które mieści się w zakresie istniejącego albo potencjalnego zapotrzebowania odnoszącego się do korzystania z utworu przez osoby trzecie.

7 J. Barta, Komentarz do art. 14 ust. 2 u.p.a.p.p., LEX/el. 2011.

8 Na określone, związane z tym wątpliwości wskazuje M. Poźniak-Niedzielska, G. Tylec (Działalność..., s. 33-48), której zdaniem w praktyce realizacja tzw. modelu zamkniętego w odniesieniu do utworów naukowych, do których stosuje się art. 14 u.p.a.p.p., oraz do utworów osób niezwiązanych z uczelnią stosunkiem pracy może być wyłączona ze względu na art. 41 ust. 3 u.p.a.p.p., zgodnie z którym nieważna jest umowa w części dotyczącej wszystkich utworów lub wszystkich utworów określonego rodzaju tego samego twórcy mających powstać w przyszłości. Wydaje się, że przewidziana $\mathrm{w}$ tym przepisie sankcja znajduje bezpośrednie zastosowanie do umów przenoszących prawa autorskie majątkowe albo do umów licencyjnych, natomiast porozumienia mające status prawny „uzgodnienia przeznaczenia”, jakkolwiek w konkretnych przypadkach mogą być zbliżone do umów licencyjnych, to jednak zachowują określoną odrębność prawną (i normatywną) związaną z celem ich prawnej dopuszczalności oraz faktycznego zawierania wskazanym $\mathrm{w}$ art. 14 ust. 2 u.p.a.p.p. W tym kontekście dyskusyjne byłoby traktowanie art. 41 ust. 3 u.p.a.p.p. jako lex specialis w stosunku do art. 14 ust. 2 u.p.a.p.p. i w każdym przypadku wywodzenie wynikających z art. 41 ust. 3 u.p.a.p.p. konsekwencji prawnych (podobnie A. Szewc, Dzieła ..., s. 23-31 w odniesieniu do relacji prawnych między art. 14 u.p.a.p.p. i art. 70 u.p.a.p.p., w kontekście ewentualnej kolizji między przepisami szczególnymi dla utworów literackich i filmowych - audiowizualnych, a także A. Stuglik, Wynagrodzenia twórców programów komputerowych - aspekt prawny i podatkowy, „Praca i Zabezpieczenie Społeczne” 2002, nr 3, s. 24 - w kwestii relacji prawnych między art. 14 u.p.a.p.p. i art. 74 ust. 3 u.p.a.p.p. dotyczącym pracowniczych programów komputerowych).

9 Podobnie D. Flisak, Komentarz do art. 14 u.p.s.p.p., LEX/el. 2015. 


\section{Propozycja określenia charakteru prawnego uzgodnienia przeznaczenia utworu naukowego i wynikającego z niego uprawnienia instytucji naukowej}

Podstawą korzystania przez osoby trzecie jest prawo do udostępniania im utworu naukowego przysługujące instytucji. Oddanie osobom trzecim utworu naukowego do korzystania stanowi jeden $\mathrm{z}$ wymienionych $\mathrm{w}$ art. 14 ust. 2 u.p.a.p.p. sposobów korzystania z tych utworów przez instytucję. Wydaje się, że $\mathrm{z}$ teoretycznego punktu widzenia korzystanie przez instytucję $\mathrm{z}$ utworu naukowego można kwalifikować jako rodzaj uprawnienia zbliżonego do typowego (podstawowego) uprawnienia wynikającego z klasycznej umowy licencyjnej ${ }^{10}$. Dozwolone obszary korzystania $\mathrm{z}$ wyżej wymienionego utworu przypominają natomiast określonego rodzaju ,pola eksploatacji”. Nie są jednak takimi polami, z czym związane jest wyłączenie możliwości stosowania do nich przepisów dotyczących pól eksploatacji zawartych w rozdziale 5 u.p.a.p.p. Można zaryzykować stwierdzenie, że uzgodnienie przeznaczenia utworu naukowego jest w tym przypadku rodzajem umowy podobnej do kontraktu licencyjnego ${ }^{11}$, w odróżnieniu np. od sytuacji korzystania przez instytucję naukową z tego utworu we własnym zakresie, czego podstawie można z kolei, nie bez wątpliwości (zasygnalizowanych na wstępie, związanych z niejednolitą wykładnią art. 14 ust. 2 u.p.a.p.p.) przypisać naturę prawną bardziej zbliżoną do licencji ustawowej ${ }^{12}$.

Podobnie jak umowa licencyjna, uzgodnienie przeznaczenia (stanowiące część umowy, w tym umowy o pracę zawartej przez instytucję naukową z jej pracownikiem albo odrębne od niej porozumienie), może być dokonane na czas określony albo nieokreślony (o czym szerzej w pkt 5). Każda z wymienionych umownych podstaw prawnych korzystania dotyczy prawnie zastrzeżonego dla korzystającego dobra niematerialnego, którym jest utwór, z tym, że w przypadku uzgodnienia przeznaczenia odnosi się to jedynie do szczególnej kategorii utworu - utworu naukowego. Zakres korzystania, zarówno w przypadku umowy licencyjnej, jak i uzgodnienia przeznaczenia może być ograniczony. Inaczej niż w przy-

10 Odmiennie E. Ferenc-Szydełko (Komentarz do art. 14 u.p.a.p.p., Legalis/el. 2016), której zdaniem podstawą uprawnienia instytucji naukowej w tym przypadku jest licencja ustawowa (mająca postać rodzaju dozwolonego użytku).

$11 \mathrm{Na}$ temat charakteru prawnego umowy licencyjnej zob. np. P. Ślęzak, Umowy w zakresie współczesnych sztuk wizualnych, Warszawa 2012, s. 183-187; B. Giesen, Umowa licencyjna w prawie autorskim. Struktura i charakter prawny, Warszawa 2013, s. 1-64, 101-144 - i literaturę przywołaną w tych pracach.

12 Zob. D. Flisak, Komentarz do art. 14 u.p.s.p.p., LEX/el. 2015. 
padku korzystania na podstawie umowy licencyjnej obszar korzystania z utworu naukowego na podstawie uzgodnienia przeznaczenia (do czego odnoszą się pkt 4 i 5), ze względu na regulację art. 14 ust. 1-2 u.p.a.p.p. co do zasady, nie może być natomiast całkowicie nieograniczony. Mieszczący się w powyższym obszarze zakres swobodnej decyzji stron uzgodnienia przeznaczenia (instytucji naukowej oraz jej pracownika) odnosi się jedynie do udostępniania utworu naukowego osobom trzecim i jest w związku z tym znacznie węższy niż w przypadku stron umowy licencyjnej, w której mogą być przewidziane zróżnicowane sposoby korzystania $\mathrm{z}$ utworu, odpowiadające wskazanym w niej polom eksploatacji. Ponadto w przypadku uzgodnienia przeznaczenia po stronie upoważnionej do korzystania - instytucji naukowej - co do zasady (zob. uwagi w pkt 5 poniżej) nie powstaje obowiązek świadczenia wzajemnego, w szczególności w stosunku do pracownika naukowego, co z kolei jest charakterystyczne dla licencjobiorcy w umowie licencyjnej ${ }^{13}$.

Dostrzegając różnice między uzgodnieniem przeznaczenia utworu a zawarciem typowej umowy licencyjnej, trzeba zauważyć też m.in., że wymienione uzgodnienie ma określone cechy zawartej z twórcą umowy o udostępnienie przez instytucję jego utworu naukowego osobom trzecim, z której jednak (w odróżnieniu od typowej umowy o świadczenie na rzecz osoby trzeciej - art. 393 k.c. ${ }^{14}$ ) nie wynikają uprawnienia tych osób do żądania udostępnienia im tego utworu. W klasycznej umowie licencyjnej nie musi być przewidziany taki sposób korzystania z utworu (naukowego). Zwykle korzystanie z utworu (w tym utworu naukowego) jest w takiej umowie uprawnieniem licencjobiorcy, chyba że przewidziana została możliwość udzielenia tzw. dalszej licencji. Licencję taką, opartą na podstawie umownej, należy wyraźnie odróżnić od korzystania z udostępnionego przez instytucję naukową utworu naukowego przez osoby trzecie na podstawie uzgodnienia przeznaczenia. Wydaje się, że pomimo zasygnalizowanego podobieństwa uzgodnienia przeznaczenia do umowy licencyjnej, ze względu na treść i zakres regulacji prawnej oraz przywołane wyżej odmienności, unormowanie art. 65 u.p.a.p.p. (z którego wynika - w przypadku wystąpienia wątpliwości dotyczącej charakteru prawnego umowy, w której nie przewidziano przeniesienia praw autorskich - domniemanie zawarcia umowy licencyjnej ${ }^{15}$ ), nie znaj-

13 Zob. w tej kwestii uwagi P. Ślęzaka (Umowy..., s. 182) i literaturę tam powołaną.

14 Ustawa z dnia 2 kwietnia 1964 r. Kodeks cywilny, tekst jedn. Dz. U. z 2017 r., poz. 459, ze zm. - dalej k.c.

15 Zob. szerzej P. Ślęzak, Umowa o rozpowszechnianie filmu, Warszawa 1999, s. 65; J. Barta, R. Markiewicz, w: Prawo autorskie i prawa pokrewne. Komentarz, Kraków 2005, s. 414. 
duje zastosowania do uzgodnienia przeznaczenia. Domniemanie to odnosi się bezpośrednio do umów o przeniesienie autorskich praw majątkowych i umów licencyjnych. Służy ono ułatwieniu rozróżnienia zwłaszcza w praktyce obrotu prawnego umów o przeniesienie praw autorskich majątkowych od umów licencyjnych, których klasycznym przykładem nie wydaje się analizowane uzgodnienie przeznaczenia - sklasyfikowane wyżej jako w określonym stopniu podobne do umów licencyjnych ${ }^{16}$.

Wydaje się, że uzgodnienie przeznaczenia należy zaliczyć do kategorii czynności prawnych zobowiązujących (a nie np. zobowiązująco-rozporządzających, upoważniających, czy też upoważniająco-zobowiązujących). Przemawiają za tym argumenty przedstawione $\mathrm{w}$ literaturze przedmiotu $\mathrm{w}$ ramach obszernej dyskusji naukowej dotyczącej charakteru prawnego umowy licencyjnej przez zwolenników poglądu o zobowiązującym charakterze tej umowy ${ }^{17}$, które wypada odnieść analogicznie do uzgodnienia przeznaczenia. Należy mieć na uwadze, że po stronie pracownika naukowego występuje obowiązek znoszenia (pati), polegający na tolerowaniu korzystania przez instytucję naukową (oraz osoby trzecie, którym utwór naukowy jest udostępniony do korzystania) z chronionego utworu, a także obowiązek nieczynienia (non facere), polegający na powstrzymywaniu się od wykonywania przysługujących mu względem instytucji naukowej (i wskazanych osób trzecich) roszczeń. Pracownik naukowy ma obowiązek przekazania instytucji naukowej utworu (np. w postaci egzemplarza), z którego instytucja naukowa może korzystać w sposób określony w uzgodnieniu przeznaczenia poprzez udostępnianie go osobom trzecim. W uzgodnieniu przeznaczenia można dopatrywać się także określonych elementów czynności prawnych upoważniających. Wynikałoby z tego pozbawienie się przez pracownika naukowego poprzez dokonanie tego uzgodnienia możliwości korzystania z tzw. zakazowej strony prawa autorskiego. Nie oznacza to jednak, że pracownik naukowy na podstawie uzgodnienia przeznaczenia pozbawia się możliwości samodzielnego korzysta-

16 Porozumienia mające status prawny „uzgodnienia przeznaczenia”, mimo że w konkretnych przypadkach mogą być podobne do umów licencyjnych, to jednak, jak wyżej zaznaczono, posiadają określoną odrębność prawną (i normatywną) związaną z celem ich prawnej dopuszczalności, wynikającym z art. 14 ust. 2 u.p.a.p.p. $Z$ tej perspektywy za nieuprawnione należałoby zatem uznać traktowanie art. 65 u.p.a.p.p. jako lex specialis w stosunku do art. 14 ust. 2 u.p.a.p.p. (podobnie A. Szewc [Dzieła..., s. 23-31] w odniesieniu do relacji prawnych między art. 14 u.p.a.p.p. i art. 70 u.p.a.p.p. i A. Stuglik [Wynagrodzenia..., s. 24] w kwestii relacji prawnych między art. 14 u.p.a.p.p. i art. 74 ust. 3 u.p.a.p.p.). Zob. także uwagi zawarte w przyp. 8.

17 Zob. w tym zakresie uwagi P. Ślęzaka (Umowy..., s. 183-187) i B. Giesen (Umowa..., s. 101-144) oraz literaturę tam przywołaną. 
nia $\mathrm{z}$ utworu naukowego. Nie dochodzi zatem w tym przypadku do osłabienia jego pozycji prawnoautorskiej. W związku z tym przyjmowanie, że uzgodnienie przeznaczenia ma charakter czynności prawnej zobowiązująco-rozporządzającej, budzi wątpliwości.

\section{Obszary korzystania $\mathrm{z}$ utworu naukowego wskazane w uzgodnieniu przeznaczenia utworu a właściwości tego utworu}

Należy przyjąć, że w „uzgodnieniu przeznaczenia utworu” mogą być wskazane obszary korzystania niekoniecznie związane z obiektywnym i powszechnie znanym przeznaczeniem utworu, jednak faktyczne (rzeczywiste) istniejące oraz osiągalne, co do których instytucja naukowa i pracownik byli zgodni. Obejmuje to obszary korzystania z utworu naukowego, w przypadku których strony ustaliły, że są one objęte „uzgodnionym przeznaczeniem” utworu. „Uzgodnione przeznaczenie utworu naukowego" powinno być odróżnione od „istniejącego obiektywnie przeznaczenia utworu", które nie zostało objęte tym uzgodnieniem. Wydaje się, co jest konsekwencją przyjęcia na wstępie jednego z wariantów interpretacji, budzącego określone wątpliwości art. 14 ust. 2 u.p.a.p.p., że w drugim przypadku instytucja naukowa może udostępniać utwór naukowy (albo zawarty w nim materiał naukowy) tylko swoim pracownikom (tj. korzystać z tego utworu we własnym zakresie).

Określone wątpliwości interpretacyjne może wywoływać zagadnienie zakresu znaczeniowego określenia „uzgodnione przeznaczenie utworu”. Mogą być one związane w szczególności z potrzebą ustalania, czy kategoria ta obejmuje właściwości (cechy) utworu niewymienione wyraźnie w uzgodnieniu (nieobjęte tym uzgodnieniem).

Nie budzi większych wątpliwości, że określenie to może obejmować przeznaczenie odwołujące się do istniejących obiektywnie, zarówno w chwili powstania stosunku pracy z pracownikiem naukowym, w momencie stworzenia utworu naukowego, jak i w chwili powstania zamiaru oraz podejmowania decyzji o jego udostępnieniu (aktualnych) i znanych twórcy oraz instytucji naukowej właściwości utworu naukowego (które umożliwiają korzystanie z niego na określonych polach eksploatacji), np. korzystanie z recenzji lub opinii w postępowaniu (np. naukowym, awansowym), na potrzeby którego zostały stworzone, korzystanie z efektów prac badawczych dla celów przyjętych jako cel ich realizacji itp.

Można natomiast rozważać, czy określenie to (,uzgodnione przeznaczenie utworu") obejmuje przeznaczenie odwołujące się do właściwości utworu 
naukowego niedostrzeżonych przez strony (pracownika naukowego i instytucję naukową), które istniały obiektywnie jeszcze przed stworzeniem utworu (np. były dostrzegane przez inne instytucje naukowe lub innych pracowników, ewentualnie inne podmioty jako istniejące w stosunku do utworów tego rodzaju), mimo że wymienione strony ich nie zauważały, w szczególności korzystanie z recenzji lub opinii w postępowaniu innym niż to, na którego potrzeby zostały stworzone, w procesie decyzyjnym organów administracji lub osób prawnych. W tym przypadku można wskazać na określone wątpliwości związane z takim rozumieniem znaczenia tego pojęcia. Właściwości te nie zostały objęte bezpośrednim uzgodnieniem instytucji naukowej i jej pracownika, a podmioty te nie zakładały w ogóle takiego zakresu udostępnienia do wykorzystania utworu naukowego przez osoby trzecie. Kwestią do dyskusji jest zatem, czy z faktem stworzenia takiego utworu naukowego, w takich okolicznościach, można w konkretnym przypadku łączyć istnienie rodzaju dorozumianego uzgodnienia przeznaczenia utworu $\mathrm{w}$ tym zakresie. Wydaje się, że przyjmowanie w tych przypadkach istnienia uzgodnienia przeznaczenia utworu per facta concludentia może być uzasadnione jedynie w wyjątkowych sytuacjach.

Wypada jednak zastanowić się, czy określenie „uzgodnione przeznaczenie utworu" może obejmować także niedostrzegane bezpośrednio przez instytucję naukową oraz jej pracownika i nieistniejące obiektywnie w chwili stworzenia utworu naukowego jego konkretne właściwości, o ile w sposób wyraźny i udokumentowany, np. w formie pisemnej (jednak bez wskazywania tych konkretnych właściwości), instytucja naukowa i pracownik umieściły w zakresie tej kategorii ewentualne, potencjalne, przyszłe właściwości, których w nie doprecyzowały w uzgodnieniu, np. korzystanie z recenzji lub opinii w postępowaniu innym niż to, na którego potrzeby zostały opracowane, w procesie decyzyjnym organów administracji lub osób prawnych - o ile instytucja naukowa oraz pracownik tak postanowiły. Należy przyjąć, że instytucja naukowa i jej pracownik mogą uzgodnić takie przeznaczenie utworu, ponieważ nie zostało to wyraźnie wyłączone (zakazane) w przepisach ustawy o prawie autorskich i prawach pokrewnych, a mieści się w zakresie tzw. swobodnej woli tych podmiotów w ukształtowaniu umownej relacji między nimi (swobody kontraktowania). W przepisach tych przewiduje się nawiązujące do tego przypadku określenia zakresu uzgodnionego przeznaczenia ograniczenia dotyczące pól eksploatacji - jedynie w odniesieniu do odrębnych (i zasadniczo różnych) od tego uzgodnienia: umowy o przeniesienie autorskich praw majątkowych oraz umowy licencyjnej (art. 41 ust. 2-4 
u.p.a.p.p.). Umowa o przeniesienie autorskich praw majątkowych może dotyczyć tylko pól eksploatacji istniejących w chwili jej zawierania oraz wyraźnie w niej wymienionych. Podobnie oddanie utworu do korzystania na podstawie umowy licencyjnej może nastąpić tylko na polach eksploatacji istniejących i wskazanych w tej umowie.

Rozważenia może w konkretnym przypadku wymagać ustalenie, czy uzgodnienie (instytucji i pracownika) może ograniczać przeznaczenie utworu do wyraźnie w nim wskazanych właściwości utworu, pomimo istnienia innych, znanych im, właściwości, które umożliwiają korzystanie z tego utworu na określonych obszarach - polach eksploatacji? Należy przyjąć, że nie jest to wyraźnie wyłączone (zakazane) w przepisach ustawy o prawie autorskim i prawach pokrewnych, a w związku z tym mieści się w zakresie powołanej wyżej swobodnej woli instytucji i jej pracownika (swobody kontraktowania). Ukształtowanie zakresu treściowego uzgodnienia przeznaczenia w tym kierunku zbliża z kolei to uzgodnienie do umowy o przeniesienie autorskich praw majątkowych oraz do umowy licencyjnej, w których strony mogą w dowolny sposób ograniczyć liczbę pól eksploatacji utworu z szerokiej grupy istniejących i dostępnych obszarów korzystania.

\section{Odplatność udostępniania utworu naukowego osobom trzecim a cel udostępniania i treść uzgodnienia przeznaczenia}

Nie ma wyraźnych podstaw prawnych do przyjęcia, że z art. 14 ust. 2 u.p.a.p.p. wynika możliwość nieodpłatnego udostępniania utworu naukowego osobom trzecim (w ramach prawnych „uzgodnionego przeznaczenia tego utworu”) wyłącznie w celach naukowo-poznawczych, a udostępnienie dla innych celów, choćby zgodnych z zakresem działalności statutowej instytucji naukowej, np. dla szeroko rozumianych niekomercyjnych (niezarobkowych) celów społecznie i gospodarczo użytecznych, musi być związane z obowiązkiem zapłaty twórcy (pracownikowi) wynagrodzenia. Przepis art. 14 ust. 2 u.p.a.p.p. nie wprowadza wprost takiego ograniczenia. Zatem wydaje się, że o ile udostępnianie utworu naukowego osobom trzecim w celach innych niż naukowo-poznawcze mieści się w zakresie uzgodnienia jego przeznaczenia, o tyle nie musi się ono łączyć z obowiązkiem zapłaty twórcy - pracownikowi - odrębnego wynagrodzenia. Wypada mieć przy tym na uwadze, że taka interpretacja art. 14 ust. 2 u.p.a.p.p. pozostaje w zgodzie (a nawet wychodzi wyraźniej naprzeciw) z postulatem praktycznego 
zastosowania efektów pracy naukowej, poza zakresem działalności ściśle naukowej (w tym działalności instytucji naukowych). $Z$ drugiej strony trzeba zauważyć, że instytucja naukowa i jej pracownik mogą wprowadzić (w uzgodnieniu przeznaczenia) zasadę odpłatności przez tę instytucję udostępniania utworu naukowego osobom trzecim ${ }^{18} \mathrm{w}$ całości albo w części, niezależnie od celów udostępnienia, co nadaje uzgodnieniu przeznaczenia jedną z właściwości (cech) występujących zwykle w umowach licencyjnych (odpłatność).

\section{Zagadnienie terminowości i dopuszczalności zmiany uzgodnienia przeznaczenia}

Wydaje się, że uzgodnienie przeznaczenia utworu może mieć charakter terminowy (ograniczony w czasie, określony), jak i bezterminowy - być dokonane (,zawarte”) na czas nieokreślony. W pierwszym przypadku podstawą czasowego odniesienia dla uzgodnienia przeznaczenia może być w szczególności czas trwania umowy o pracę z pracownikiem naukowym albo zatrudnienia na określonym stanowisku, okres realizacji prac badawczych lub naukowych, których efektem było stworzenie utworu naukowego, czy też np. okres utrzymania efektów (rezultatów) projektu, w wyniku realizacji którego został stworzony utwór naukowy, ewentualnie inny przedział czasu mierzony tradycyjnie w dniach, miesiącach, latach itp. Uzgodnieniem bezterminowym będzie z kolei także uzgodnienie dokonane (,zawarte") na czas życia pracownika naukowego, którego nie można z całą pewnością dokładnie określić.

Ponadto, jak każda umowa, uzgodnienie przeznaczenia utworu naukowego może podlegać zmianom. Zmiany te powinny respektować generalny normatywny wymóg ochrony praw jego twórcy - pracownika naukowego - a także mieścić się $\mathrm{w}$ zakresie wyznaczonym przez treść art. 14 ust. 1-2 u.p.a.p.p. i wynikający z niej szczególny charakter utworu naukowego, tj. przede wszystkim uwzględniać właściwości utworu naukowego zwłaszcza w odniesieniu do określanych $\mathrm{w}$ uzgodnieniu przeznaczenia obszarów korzystania przy zastosowaniu kryteriów zaproponowanych w pkt 4 tego artykułu. W każdym przy-

18 Podobnie E. Czarny-Drożdżejko, Wybrane zagadnienia z zakresu prawa autorskiego w prawie o szkolnictwie wyższym, „Przegląd Sądowy” 2016, nr 9, s. 88 i n. Zdaniem autorki zawarte w art. 14 ust. 2 u.p.a.p.p. określenie „bez odrębnego wynagrodzenia” odnosi się jedynie do korzystania $\mathrm{z}$ materiału naukowego zawartego w utworze naukowym, a $\mathrm{z}$ uwagi na to, że w odniesieniu do udostępniania utworu należy z pracownikiem naukowym zawrzeć odrębną umowę, można w niej uregulować także kwestie jego wynagrodzenia. 
padku wymagają one zgodnej woli stron - pracownika i instytucji naukowej. Nie stanowi odstępstwa od tej generalnej zasady sytuacja, w której jedna ze stron uzgodnienia przeznaczenia wyraziła zgodę na jego zmianę w przewidzianym w nim zakresie w trybie jednostronnego oświadczenia woli złożonego drugiej stronie. Jednostronna zmiana uzgodnienia przeznaczenia przez jedną ze stron jest bowiem w takim przypadku objęta wcześniejszą akceptacją takiej zmiany przez drugą z nich. Zmiany te wymagają, jak można sądzić, przynajmniej formy prawnej przewidzianej dla podstawy uzgodnienia, tj. albo formy właściwej dla zawarcia umowy o pracę, albo w formy właściwej dla zawarcia pozaumownego porozumienia (uzgodnienia).

\section{Podsumowanie}

W podsumowaniu niniejszego wywodu można pokusić się przynajmniej o zasygnalizowanie określonych, ważniejszych konkluzji:

1) „uzgodnienie przeznaczenia utworu naukowego” ma określone cechy zbliżone do klasycznej umowy licencyjnej (np. w zakresie: umownej podstawy oddania utworu do korzystania, możliwości wskazania określonych obszarów korzystania, czasu trwania, w określonym zakresie - przedmiotu korzystania), ale można wskazać także na istotne różnice między tym uzgodnieniem a umową licencyjną, np.: zakres uzgodnienia przeznaczenia ograniczony do udostępnienia utworu naukowego osobom trzecim, zasadniczo brak obowiązku świadczenia wzajemnego po stronie instytucji naukowej, korzystanie z utworu na podstawie umowy licencyjnej zwykle nie obejmuje upoważnienia do oddawania go do „dalszego" korzystania innym osobom, generalnie mniejszy rygoryzm formalny uzgodnienia przeznaczenia, zasadniczo nieodpłatny charakter uzgodnienia przeznaczenia, brak możliwości stosowania wprost do uzgodnienia przeznaczenia domniemania $z$ art. 65 u.p.a.p.p. - wypada zatem je uznać za konstrukcję prawną podobną (zbliżoną) do umowy licencyjnej, jednak posiadającą, ze względu na treść, zakres i cel regulacji art. 14 ust. 2 u.p.a.p.p., prawną oraz normatywną odrębność od tej umowy;

2) „uzgodnienie przeznaczenia utworu naukowego” należy zaliczyć do grupy czynności prawnych zobowiązujących (a nie zobowiązująco-rozporządzających, upoważniających czy też upoważniająco-zobowiązujących);

3) „uzgodnienie przeznaczenia utworu naukowego” może odnosić się do objętych zgodną wolą (akceptacją) instytucji naukowej i pracownika ewentual- 
nych, potencjalnych właściwości tego utworu, które nie istniały w chwili dojścia do skutku wymienionego uzgodnienia (a zatem niewskazanych wyraźnie w tym uzgodnieniu rodzaju przyszłych właściwości), inaczej niż w przypadku dopuszczalnych prawnie właściwości objętych polami eksploatacji wskazanymi w umowie licencyjnej;

4) unormowanie art. 14 ust. 2 u.p.a.p.p. obejmuje uzgodnienie oddania utworu naukowego do korzystania także w celach innych niż naukowo-poznawcze, o ile cele te mieszczą się w zakresie działalności statutowej instytucji naukowej, zwłaszcza gdy mają charakter niezarobkowy, np. społecznie i gospodarczo użyteczny.

\section{Akty normatywne}

Ustawa z dnia 4 lutego 1994 r. o prawie autorskim i prawach pokrewnych, tekst jedn. Dz. U. z 2017 r., poz. 880, ze zm.

Ustawa z dnia 2 kwietnia 1964 r. Kodeks cywilny, tekst jedn. Dz. U. z 2017 r., poz. 459, ze zm.

\section{Literatura}

Barta J., Czajkowska-Dąbrowska M., Ćwiąkalski Z., Markiewicz R., Traple E., Prawo autorskie i prawa pokrewne. Komentarz, Kraków 2005, s. 414.

Barta J., Komentarz do art. 14 ust. 2 u.p.a.p.p., LEX/el. 2011, pkt 7 i n.

Błeszyński J., Ochrona utworów naukowych, technicznych i popularno-naukowych w świetle polskiego prawa autorskiego, „Wiadomości ZAiKS-u” 1981, nr 1-2, s. 21.

Ferenc-Szydełko E., Komentarz do art. 14 u.p.a.p.p., Legalis/el. 2016.

Ferenc-Szydełko E., Ochrona dzieł naukowych w świetle prawa autorskiego, „Zeszyty Naukowe Uniwersytetu Szczecińskiego" 2004, z. 14, s. 155 i n.

Flisak D., Komentarz do art. 14 u.p.s.p.p., LEX/el. 2015.

Giesen B., Umowa licencyjna w prawie autorskim. Struktura i charakter prawny, Warszawa 2013, s. 1-64, 101-144.

Kędzierska-Cieślak A., Pierwszeństwo instytucji naukowej do opublikowania utworu naukowego jej pracownika, „Państwo i Prawo” 1996, z. 81 i n.

Niewęgłowski A., Wyniki prac badawczych w obrocie cywilnoprawnym, Warszawa 2010, s. 66-74, 170-177, 189-192.

Poźniak-Niedzielska M., Tylec G., Działalność naukowo-dydaktyczna na wyższej uczelni w świetle prawa autorskiego, „Państwo i Prawo” 2009, z. 5, s. 33-48. 
Stec P., Uczelnia jako podmiot praw na dobrach niematerialnych, „Państwo i Prawo” 2008, z. 1, s. 51.

Stuglik A., Wynagrodzenia twórców programów komputerowych-aspekt prawny i podatkowy, „Praca i Zabezpieczenie Społeczne” 2002, nr 3, s. 24.

System prawa prywatnego, t. 13: Prawo autorskie, red. J. Barta, Warszawa 2007, s. 101.

Szewc A., Dzieła naukowe i ich status w prawie autorskim, „Państwo i Prawo” 1997, z. 10, s. $23-31$.

Ślęzak P., Umowa o rozpowszechnianie filmu, Warszawa 1999, s. 65.

Ślęzak P., Umowy w zakresie współczesnych sztuk wizualnych, Warszawa 2012, s. 183-187.

\section{THE AGREEMENT OF DESTINATION AS THE PREMISE OF USING \\ OF THE SCIENTIFIC WORK BY A SCIENTIFIC INSTITUTION TROUGH MAKING IT AVAILABLE TO THIRD PARTIES WITHIN THE SCOPE SPECIFIED IN ART. 14 PAR. 2 IN FINE OF THE LAW ON COPYRIGHT AND RELATED RIGHTS}

\section{Summary}

The article commented on the agreed destination constituting in accordance with Article 14 paragraph 2 of LCRR made available by the scientific institution of the research work created by its employee to a third party. It sets out in particular the legal relation between agreement of destination and the agreement from which such arrangement may result, proposed the legal arrangements of the agreement of destination and resulting therefrom powers of scientific institution from the perspective of the qualities of that agreement key of its legal nature, and also indicated the fundamental relationship between legally acceptable areas to provide (make available) of the scientific work and the properties of this work. The article also addresses the issue of the legitimacy of conditionality to free access and scope of made available of the scientific work of the purpose of this made available, in addition to the issue of the timeliness and changes of agreement of destination. The final part of the article are the conclusions that summarize key insights referred to in its content.

Keywords: scientific institution, agreement of destination, scientific work, made available of the scientific work third parties, areas of made available 